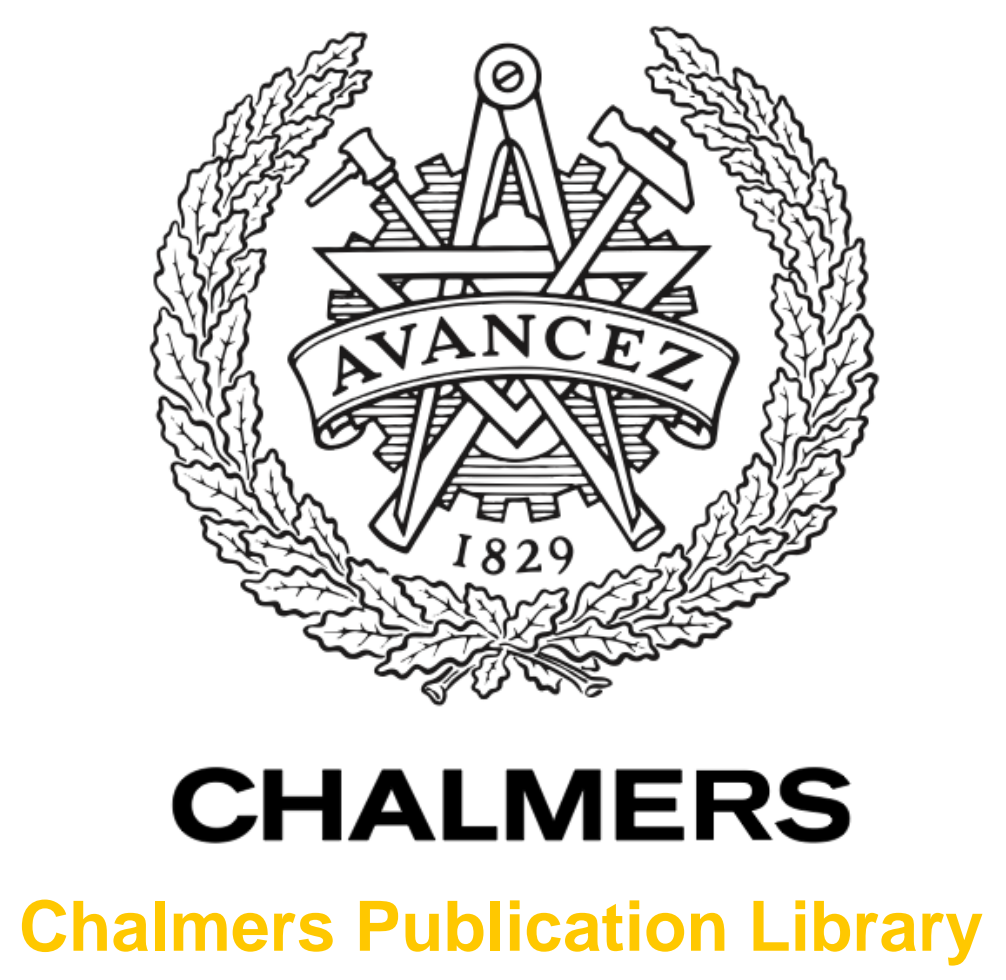

\title{
Single-Crystal-to-Single-Crystal Transformation of a Novel 2-Fold Interpenetrated Cadmium-Organic Framework with Trimesate and 1,2-Bis(4-pyridyl)ethane into the Thermally Desolvated Form Which Exhibits Liquid and Gas Sorption Properties
}

This document has been downloaded from Chalmers Publication Library $(\mathrm{CPL})$. It is the author's version of a work that was accepted for publication in:

Crystal Growth \& Design (ISSN: 1528-7483)

\author{
Citation for the published paper: \\ Husain, A. ; Ellwart, M. ; Bourne, S. (2013) "Single-Crystal-to-Single-Crystal \\ Transformation of a Novel 2-Fold Interpenetrated Cadmium-Organic Framework with \\ Trimesate and 1,2-Bis(4-pyridyl)ethane into the Thermally Desolvated Form Which Exhibits \\ Liquid and Gas Sorption Properties". Crystal Growth \& Design, vol. 13(4), pp. 1526-1534. \\ http://dx.doi.org/10.1021/cg301760a
}

Downloaded from: http://publications.lib.chalmers.se/publication/177691

Notice: Changes introduced as a result of publishing processes such as copy-editing and formatting may not be reflected in this document. For a definitive version of this work, please refer to the published source. Please note that access to the published version might require a subscription. 


\title{
Single-crystal-to-single-crystal transformation of a novel 2-fold interpenetrated
} cadmium-organic framework with trimesate and 1,2-bis(4-pyridyl)ethane into the thermally desolvated form which exhibits liquid and gas sorption properties Ahmad Husain $^{\text {a }}$, Mario Ellwart ${ }^{\mathrm{b}}$, Susan A. Bourne ${ }^{\mathrm{a}}$, Lars Öhrström ${ }^{\mathrm{c}}$ and Clive L. Oliver ${ }^{\mathrm{a} *}$

${ }^{a}$ Centre for Supramolecular Chemistry Research, Department of Chemistry, University of Cape Town, Rondebosch, 7701, South Africa

${ }^{b}$ Department of Chemistry, Ludwig-Maximilians-Universität, München, Germany

${ }^{c}$ Chemical and Biological Engineering, Physical Chemistry, Chalmers University of Technology, Kemivägen 10, Göteborg, Sweden

E-mail: Clive.Oliver@uct.ac.za (Dr. Clive L. Oliver)

\begin{abstract}
A novel 2-fold interpenetrated, pillared, cadmium metal-organic framework namely $[\mathrm{Cd}(\mathrm{HBTC}) \mathrm{BPE}]_{\mathrm{n}} \cdot \mathrm{nDMF}$ has been synthesized using 1,3,5-benzenetricarboxylic acid and 1,2-bis(4-pyridyl)ethane (BPE). This compound has been desolvated and subjected to various liquids and gases for sorption studies. Structures of the as-synthesized (1), desolvated (2) and resolvated in benzene (3) have been determined by single-crystal X-ray diffraction analysis and further characterized by elemental analysis, IR spectra, and TG/DSC analysis. Single crystal X-ray analysis revealed a 2-fold interpenetrated, 3-dimensional (3D) framework which exhibits a 3,5-connected network with the Schläfli symbol of $\left[\left(6^{3}\right)\left(6^{9} .8\right)\right.$ and $h m s$ topology. Compound 1 exhibits a temperature-induced single-to-crystal-single-crystal (SCSC) transformation upon the release of N,N'-dimethylformamide molecules forming compound 2 (stable up to $300{ }^{\circ} \mathrm{C}$ ). SC-SC transformation is also observed when it is immersed in benzene, chloroform, 1,4-dioxane and tetrahydrofuran. The uptake of different solvent molecules was analyzed and desolvated samples selectively adsorb benzene, chloroform, 1,4-dioxane and THF molecules over other selected polar solvents. Gas $\left(\mathrm{N}_{2}, \mathrm{CO}_{2}\right.$ and $\mathrm{N}_{2} \mathrm{O}$ ) sorption experiments were also performed and structure showed $2.5 \% \mathrm{~N}_{2}, 4.5 \%$ $\mathrm{CO}_{2}$ and $3.4 \% \mathrm{~N}_{2} \mathrm{O}$ absorption by mass at room temperature and moderate gas pressures $(\sim 10$ bar).
\end{abstract}




\section{Introduction}

Metal-organic frameworks (MOFs) have extended structures and typically contain either single or polynuclear metal centers interconnected by bridging organic ligands into 1D, 2D- or 3D- networks. Owing to their high specific surface areas, tunable structures and functionalities, uniform pore size and high degree of porosity, they have emerged as a promising class of materials for gas storage and separation, particularly for hydrogen, methane, and carbon dioxide. ${ }^{1}$ As a building block to construct MOFs, 1,3,5benzenetricarboxylic acid $\left(\mathrm{H}_{3} \mathrm{BTC}\right)$ ligand exhibits a variety of coordination modes and has the capability of generating coordination architectures of diverse size and shape. There have been many reports on infinite $1 \mathrm{D}, 2 \mathrm{D}$ and $3 \mathrm{D}$ coordination polymers using $\mathrm{H}_{3} \mathrm{BTC}$ as a starting material in various states of deprotonation. ${ }^{2}$ MOFs constructed by mixed ligands of pyridyl groups and carboxylate groups not only incorporate interesting properties of different functional groups but also lend themselves to a great variety of structures. The recent upsurge of interest in these materials is due to the robustness of MOFs with mixed ligands on loss of included solvent molecules. The high degree of porosity within MOFs can provide the necessary space to take up gas molecules, while the tunable pore sizes/curvatures and functionalized pore surfaces can be utilized to direct strong interactions with gas molecules. ${ }^{3}$ Single-crystal-to-single-crystal (SC-SC) transformations in MOFs, have attracted considerable attention as an interesting solid-state phenomenon ${ }^{4}$ and are usually induced by various stimuli such as heat ${ }^{5}$, light ${ }^{6}$, solvent molecules ${ }^{7}$ or redox reagents. ${ }^{8}$ Kitagawa and coworkers described a series of highly flexible MOFs using tris(2-carboxyethyl)isocyanurate (tci), which included $\left\{\left[\mathrm{Ce}(\mathrm{tci})\left(\mathrm{H}_{2} \mathrm{O}\right)_{2}\right] \cdot 2 \mathrm{H}_{2} \mathrm{O}\right\}_{\mathrm{n}}, \quad\left\{\left[\operatorname{Pr}(\mathrm{tci})\left(\mathrm{H}_{2} \mathrm{O}\right)_{2}\right] \cdot 2 \mathrm{H}_{2} \mathrm{O}\right\}_{\mathrm{n}} \quad$ and $\left\{\left[\mathrm{Cu}_{2}(\mathrm{tci})(\mathrm{OH})\left(\mathrm{H}_{2} \mathrm{O}\right)_{3}\right] \cdot 1.5 \mathrm{H}_{2} \mathrm{O}\right\}_{\mathrm{n}}$ that exhibited reversible SC-SC transformation from 2D- to 3D frameworks via thermal dehydration/rehydration processes ${ }^{9}$ which involve cleavage and generation of coordination bonds. Perles et al. reported Sc(III)-based MOFs $\left\{\left[\mathrm{Sc}_{2}(\mathrm{OH})\left(\mathrm{O}_{2} \mathrm{CC}_{2} \mathrm{H}_{4} \mathrm{CO}_{2}\right)_{2.5}\right]\right\}_{\mathrm{n}}, \quad\left\{\left[\mathrm{Sc}_{2}\left(1,5-\mathrm{O}_{3} \mathrm{SC}_{10} \mathrm{H}_{6} \mathrm{SO}_{3}\right)(\mathrm{OH})_{4}\right]\right\}_{\mathrm{n}} \quad$ and $\quad\left\{\left[\mathrm{Sc}_{2}(2,6-\right.\right.$ $\left.\left.\left.\mathrm{O}_{3} \mathrm{SC}_{10} \mathrm{H}_{6} \mathrm{SO}_{3}\right)(\mathrm{OH})_{4}\right]\right\}_{\mathrm{n}}$ with exceptional thermal stability up to $350-500{ }^{\circ} \mathrm{C}$ but didn't show any SC-SC transformation. ${ }^{10}$ Song et al. reported ${ }^{11}$ the first SC-SC transformation observed in $4 f$-based MOFs, namely the dehydration of $\left[\mathrm{Dy}_{2}(\text { phen })_{2}(\mathrm{~L})_{6}\right] \cdot 2 \mathrm{H}_{2} \mathrm{O}$ to anhydrous phase $\left.\left[\mathrm{Dy}_{2} \text { (phen }\right)_{2}(\mathrm{~L})_{6}\right]$ (where $\mathrm{L}$ is $\beta$-naphthoic acid and phen is phenanthroline) by calcinations under vacuum at $160{ }^{\circ} \mathrm{C}$ for $24 \mathrm{~h}$. Bernini et al. showed ${ }^{12}$ a reversible temperature induced SC-SC transformation in $\left[\mathrm{Yb}\left(\mathrm{C}_{4} \mathrm{H}_{4} \mathrm{O}_{4}\right)_{1.5}\right]$ which occurred at $130{ }^{\circ} \mathrm{C}$. Cao et al. reported the MOFs $\left[\mathrm{M}(\mathrm{OBPT})_{2}\right] \cdot 0.6 \mathrm{H}_{2} \mathrm{O}$ (where OBPT = 4,6-bis(4-pyridyl)-1,3,5-triazin-2-ol and $\mathrm{M}=\mathrm{Co}$, $\mathrm{Ni}$ ) which exhibits reversible SC-SC transformation driven by thermal treatment involving 
dehydration and rehydration processes. ${ }^{13}$ Xue et al. reported ${ }^{14}\left[\mathrm{Cd}\left(\mu-\mathrm{OH}_{2}\right)(\mathrm{bct})\right]$ (where bct is bis(carboxymethylmercapto)-1,3,4-thiadiazole acid) to exhibit SC-SC transformation upon heating at $180{ }^{\circ} \mathrm{C}$ under vacuum into dehydrated $[\mathrm{Cd}(\mathrm{bct})]$.

Previous work on the reaction between $\mathrm{Cd}(\mathrm{II})$ and $\mathrm{H}_{3} \mathrm{BTC}$ has yielded a number of MOF structures based on either $\mathrm{H}_{3} \mathrm{BTC}$ or mixed ligand systems, with the majority of these formed under hydrothermal conditions. Paz et al. reported ${ }^{15}$ hydrothermal reaction between $\mathrm{Cd}\left(\mathrm{NO}_{3}\right)_{2}$, trimesic acid $\left(\mathrm{H}_{3} \mathrm{BTC}\right)$ and 1,2-bis(4-pyridyl)ethane (BPE) in the presence of triethylamine to yield, $\left[\mathrm{Cd}_{1.5}(\mathrm{BTC})(\mathrm{BPE})\left(\mathrm{H}_{2} \mathrm{O}\right)_{2}\right] \cdot\left(\mathrm{H}_{2} \mathrm{O}\right)$. The authors reported that the absence of the base triethylamine instead yielded layered structures. Herein we report that when we used the same starting materials with a binary water and N,N'-dimethylformamide (DMF) solvent system, and in the absence of triethylamine, a porous, 3-dimensional MOF $[\mathrm{Cd}(\mathrm{HBTC}) \mathrm{BPE}]_{\mathrm{n}} \cdot \mathrm{nDMF}$ was synthesized. The synthesized MOF exhibits SC-SC transformation upon desolvation and subsequent sorption of liquid and gaseous solvent molecules. Liquid sorption selectivity was towards nonpolar solvents such as benzene, toluene, THF, $\mathrm{CHCl}_{3}$, and 1,4-dioxane, whilst gas sorption selectivity favoured $\mathrm{CO}_{2}, \mathrm{~N}_{2}$ and $\mathrm{N}_{2} \mathrm{O}$ over $\mathrm{H}_{2}$.

\section{Experimental Section}

Materials and Physical Measurements. All chemicals were of reagent grade, purchased from commercial sources, and used without further purification.

Elemental analysis was performed on a Thermo Flash EA-1112 CHNS-O Elemental Analyzer. The IR spectra were obtained from $\mathrm{KBr}$ pellets in the range $4000-400 \mathrm{~cm}^{-1}$, using a Perkin-Elmer Spectrum 100 FT-IR spectrometer.

Hot-stage microscopy was performed on a Nikon SMZ-10 stereoscopic microscope fitted with a Linkam THMS600 hot stage and a Linkam TP92 control unit. Samples were placed under silicone oil on a cover slip and heated at $10{ }^{\circ} \mathrm{C} \mathrm{min}^{-1}$. Thermal events were monitored with a Sony Digital Hyper HAD colour video camera and captured using the Soft Imaging System program analysis. ${ }^{16}$

TG/DTG measurements were performed at a heating rate of $10{ }^{\circ} \mathrm{C} \min ^{-1}$ in the temperature range $25-600{ }^{\circ} \mathrm{C}$, under a dry nitrogen flow of $60 \mathrm{~mL} \mathrm{~min}^{-1}$ on a TGA Q500 instrument. Approximately 2-5 mg of sample was placed in an open aluminum crucible.

DSC measurements were performed at a heating rate of $10{ }^{\circ} \mathrm{C} \min ^{-1}$ in the temperature range $25-400{ }^{\circ} \mathrm{C}$, under a dry nitrogen flow of $50 \mathrm{~mL} \mathrm{~min}{ }^{-1}$ on a DSC Q200 
instrument. Approximately 1-2 mg of sample was placed in an aluminum pan with a lid. A sealed and empty pan was used as a reference.

Powder XRD analysis was performed on a HUBER-Guinier 670 Imaging Plate X-ray powder diffractometer using $\mathrm{Cu} \mathrm{K \alpha}$ radiation $(\lambda=1.5405 \AA)$ generated by a Philips X-ray generator at $40 \mathrm{kV}$ and $20 \mathrm{~mA}$. A sample was placed in a $1 \mathrm{~mm}$ capillary tube, and a diffraction pattern was acquired under ambient conditions in transmission mode while the sample rotation axis was perpendicular to the beam.

\section{Synthesis of 1}

Trimesic acid (20 mg, $0.095 \mathrm{mM})$ and 1,2-bis(4-pyridyl)ethane (18 mg, $0.095 \mathrm{mM})$ were dissolved in $4.8 \mathrm{~mL}$ DMF whereas $\mathrm{Cd}\left(\mathrm{NO}_{3}\right)_{2} \cdot 4 \mathrm{H}_{2} \mathrm{O}(29 \mathrm{mg}, 0.095 \mathrm{mM})$ was dissolved in $3.6 \mathrm{~mL} \mathrm{H}_{2} \mathrm{O}$ and acidified with $\mathrm{H}_{2} \mathrm{SO}_{4}(1 \mathrm{M}, 0.2 \mathrm{~mL})$. Both the solutions were heated and hot clear solutions were combined in a sealed vial and kept in a Dewar flask. The solution was slowly cooled in Dewar flask from $80{ }^{\circ} \mathrm{C}$ to room temperature over a period of 2 days which yielded good quality colorless crystals (17 mg, 35\%). Anal. Calc: for $\mathrm{C}_{24} \mathrm{H}_{24} \mathrm{~N}_{3} \mathrm{O}_{7} \mathrm{Cd}_{1}$ $(\mathrm{FW}=578.88): \mathrm{C}, 49.75 ; \mathrm{H}, 4.14 ; \mathrm{N}, 7.25$. Found: $\mathrm{C}, 49.48 ; \mathrm{H}, 4.00 ; \mathrm{N}, 7.45 . \mathrm{IR}\left(\mathrm{KBr}, \mathrm{cm}^{-}\right.$ $\left.{ }^{1}\right)$ : 3361, 2936, 1612, 1576, 1504, 1434, 1369, 1224, 1072, 1016, 831, 756, 691, 548, 487.

\section{Synthesis of 2}

Heating the colorless crystals of $\mathbf{1}$ at $300^{\circ} \mathrm{C}$ for 5 hours in an oven under vacuum results in the formation of $\mathbf{2}$. The crystals were stable and only the solvent was removed.

\section{Synthesis of 3, 4 and 5}

Crystals of 2 were soaked in benzene (3), chloroform (4) and THF (5) and checked for their respective unit cells. It was observed that the unit cell values similar to solvated 1. Data were collected for $\mathbf{3}, \mathbf{4}$ and $\mathbf{5}$ but only in the case of $\mathbf{3}$ could the host framework be satisfactorily refined. In all cases the guest molecules were too disordered to be assigned despite their presence being confirmed by TG results.

Single Crystal X-ray Diffraction Analysis and Structure Determination: Suitable single crystals of 1, 2, 3, 4 and 5 were selected and coated with oil before being mounted in air onto a loop. The data collection for $\mathbf{1}$ and 3, 4 and $\mathbf{5}$ was carried out with a Bruker DUO APEX II CCD diffractometer at 173(2) K using an Oxford Cryostream-700. Data reduction and cell 
refinement were performed using SAINT-Plus, ${ }^{17}$ and the space group was determined from systematic absences by XPREP ${ }^{18}$ and confirmed using the program Layer. ${ }^{19}$

The data collection for 2 was carried out with a Nonius Kappa CCD diffractometer at 173(2) K using an Oxford Cryostream-600. Data reduction and cell refinement were performed using DENZO, ${ }^{20}$ and the space group was determined from systematic absences by XPREP. ${ }^{18}$

Graphite monochromated Mo $\mathrm{K} \alpha(\lambda=0.71073 \AA)$ radiation was used in both cases. The X-ray diffraction data have been corrected for Lorentz-polarization factor and scaled for absorption effects by multi-scan using SADABS. ${ }^{21}$ The structures were solved by direct methods, implemented in SHELXS-97. ${ }^{22}$ Refinement procedure by full-matrix least-squares methods based on $F^{2}$ values against all reflections have been performed by SHELXL-97, ${ }^{22}$ including anisotropic displacement parameters for all non-H atoms.

Calculations concerning the molecular geometry, the affirmation of chosen space groups and the analysis of hydrogen bonds were performed with PLATON. ${ }^{23}$ The molecular graphics were rendered with ORTEP- $3^{24}$ and MERCURY (Version 3.0). ${ }^{25}$ The calculated PXRD patterns of 1, 2 and $\mathbf{3}$ were generated by Lazy Pulverix. ${ }^{26}$ The crystal parameters, data collection, and refinement results for $\mathbf{1}-\mathbf{3}$ are summarized in Table 1.

CCDC 908241-908243 contain the supplementary crystallographic data for this paper. These data can be obtained free of charge via www. ccdc.cam.ac.uk/data_request/cif [or from the Cambridge Crystallographic Data Centre (CCDC), 12 Union Road, Cambridge CB2 1EZ, U.K.; fax: +44(0)1223-336033; e-mail: deposit@ccdc.cam.ac.uk].

\section{Gas sorption analysis}

The procedure in the gas sorption analysis was followed according to the method described by Atwood et al. ${ }^{27}$ The apparatus consisted of two chambers A and B which were connected to pressure sensors $P_{\mathrm{a}}$ and $P_{\mathrm{b}}$. The chambers were connected to a gas line while the gas-flow into and between the chambers was regulated by two valves. Chamber $\mathrm{A}$ is left empty as a control, while chamber B contains the sample of known mass and the whole system was evacuated under heat $\left(65^{\circ} \mathrm{C}\right.$, maximum of the equipment) in order to remove any residual solvent. After cooling down the system to $25{ }^{\circ} \mathrm{C}$, approximately 20 bar of pressure was released from the gas cylinder into chamber A. The valve between the chambers was then opened and closed rapidly, allowing a certain amount of gas into chamber B (volumes of both A and B were known). The pressure in chamber A remained constant and any decrease in the pressure in chamber $\mathrm{B}$ indicated that gas was being sorbed by the sample. Gas 
pressures in chambers $\mathrm{A}$ and $\mathrm{B}$ are monitored using the program Absorbance. ${ }^{28}$ From the measurement of the decrease in pressure over time, the percentage sorption by mass of the material was calculated.

\section{Results \& Discussion}

The reaction between $\mathrm{Cd}\left(\mathrm{NO}_{3}\right)_{2} \cdot 4 \mathrm{H}_{2} \mathrm{O}$, trimesic acid $\left(\mathrm{H}_{3} \mathrm{BTC}\right)$ and 1,2-bis(4pyridyl)ethane (BPE) gives rise to a highly crystalline product formulated as $[\mathrm{Cd}(\mathrm{HBTC}) \mathrm{BPE}]_{\mathrm{n}} \cdot \mathrm{nDMF}(\mathbf{1})$ (Scheme 1), in which infinite 2D- sheets pillared by flexible bipyridyl ligands to form a 3D framework. Interestingly, heating the single crystals of $\mathbf{1}$ at $300{ }^{\circ} \mathrm{C}$ for $5 \mathrm{~h}$ under vacuum resulted in a SC-SC transformation of $\mathbf{1}$ into the desolvated form 2 formulated as $[\mathrm{Cd}(\mathrm{HBTC}) \mathrm{BPE}]_{\mathrm{n}}$ with double the unit cell volume of $\mathbf{1}$.

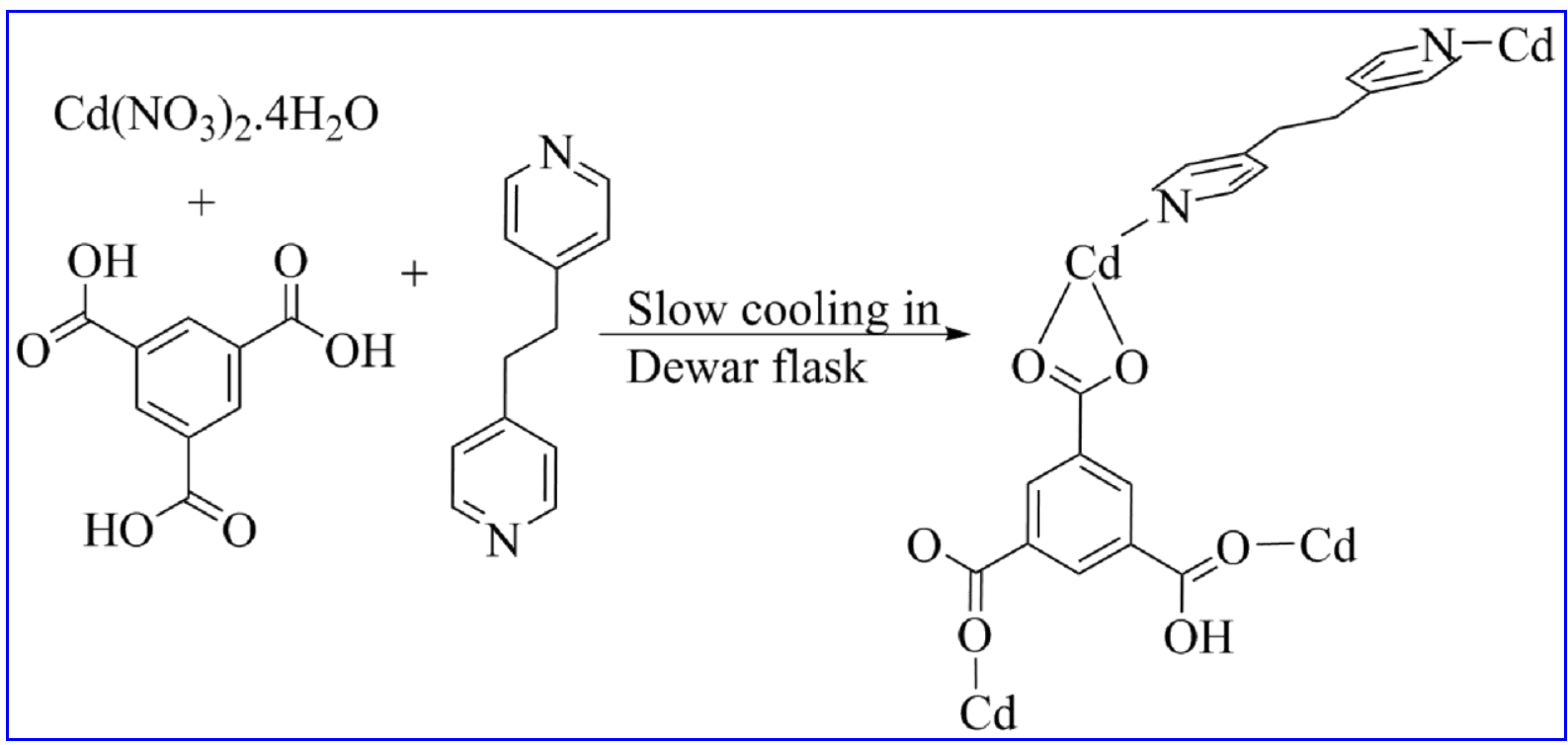

Scheme 1 Synthesis of 1.

\section{Structure of 1}

$\mathrm{X}$-Ray single-crystal analysis reveals that the structure contains a distinct repeating structural motif containing a unique $\mathrm{Cd}^{2+}$ cation in a distorted octahedral coordination geometry (Figure 1). Crystallographic data, selected bond lengths and bond angles are listed in Tables 1,2 \& S1. The asymmetric unit of 1 consists of 0.5 units of $\mathrm{Cd}(\mathrm{II}), \mathrm{HBTC}^{2-}, \mathrm{BPE}$ and DMF. Cd(1) is coordinated to four oxygen donor atoms from three $\mathrm{HBTC}^{2-}$ anions in the equatorial plane and to two nitrogen donor atoms from two 1,2-bis(4-pyridyl)ethane ligands occupying the apical positions (Figure 1). The $\mathrm{Cd}-\mathrm{O}$ and $\mathrm{Cd}-\mathrm{N}$ bond distances are $2.331 \AA$ (average) and 2.319(6) $\AA$ (Table 2 \& S1) respectively. Each trimesate anion bridges three 
metal centers through its three functional groups in two different coordination modes (Scheme 1 and Figure 1) to form 2D parallelogram-like sheets $[\mathrm{Cd}(\mathrm{HBTC})]_{\mathrm{n}}$ parallel to the $a b$ plane. Adjacent sheets are connected by BPE ligands to form a 3D layered framework. The first carboxylate group $(\mathrm{C} 1 / \mathrm{O} 1 / \mathrm{O} 2)$ is bonded to $\mathrm{Cd}^{2+}$ in a symmetrical bidentate chelating mode with the angle subtended at the metal atom being $55.5(2)^{\circ}$ whilst the two carboxylic acid groups bond via the carbonyl oxygen atoms (O3 and $\mathrm{O} 5)$ in a monodentate fashion (Scheme 1). The carboxylate and carboxylic acid groups are coplanar with respect to the phenyl ring. The $\mathrm{Cd}---\mathrm{Cd}$ distances across the parallelogram-like sheets $[\mathrm{Cd}(\mathrm{HBTC})]_{\mathrm{n}}$ are 10.462 and $9.364 \AA$ along the $a$ and $b$-axes, respectively.

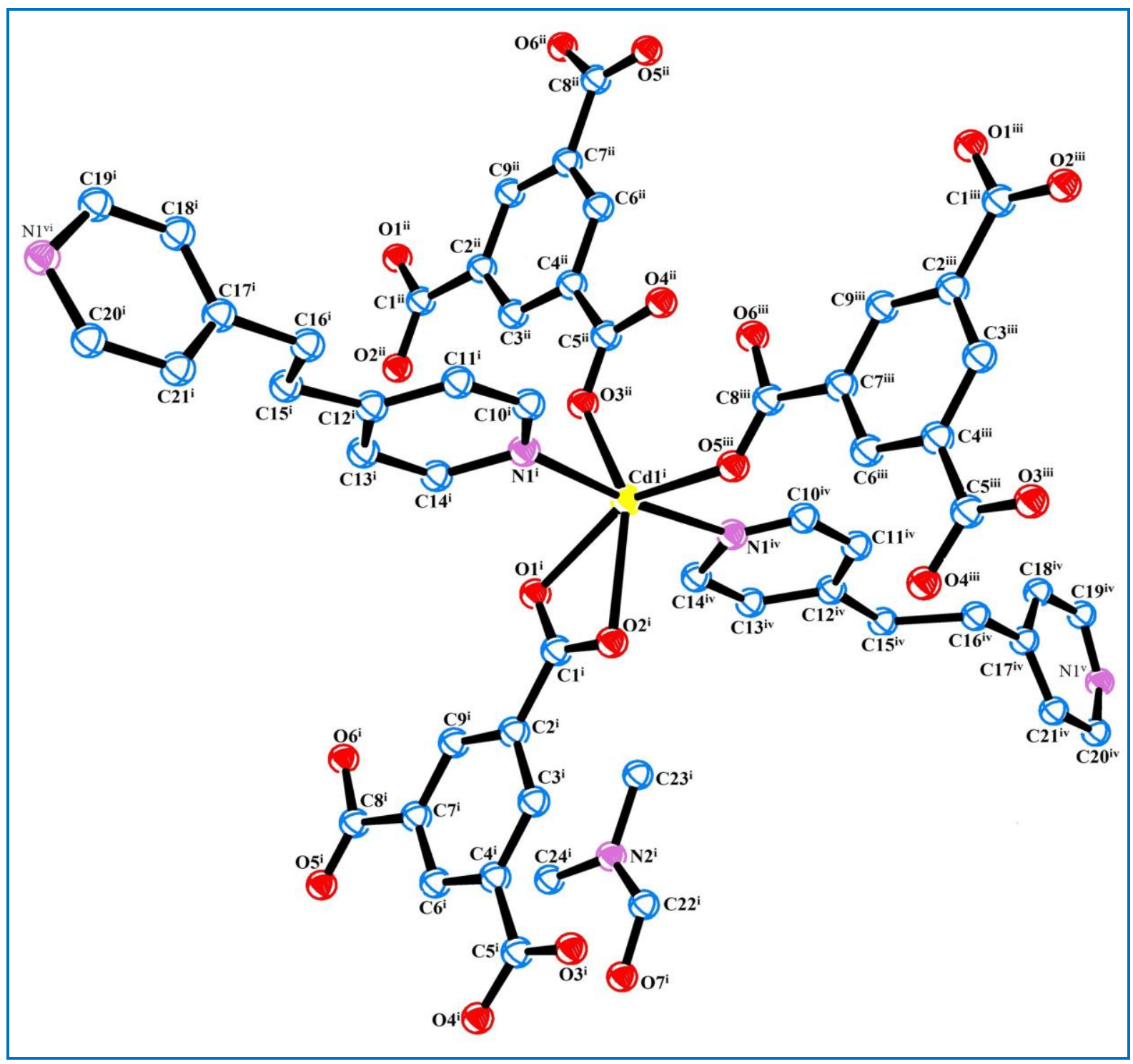

Figure 1. ORTEP plot of 1 showing coordination environment of $\mathrm{Cd}(\mathrm{II})$ (thermal ellipsoids are drawn at the $30 \%$ probability level). Disordered atoms and hydrogen atoms have been omitted for clarity. Symmetry equivalent positions are: (i) $\mathrm{x}, \mathrm{y}, \mathrm{z}$ (ii) $1-\mathrm{x}, 1 / 2+\mathrm{y}, 1 / 2-\mathrm{z}$

(iii) $1+\mathrm{x}, \mathrm{y}, \mathrm{z}$ (iv) $\mathrm{x}, \mathrm{y}, 1 / 2-\mathrm{z}$ (v) $\mathrm{x}, \mathrm{y}, \mathrm{z}-1$ (vi) $\mathrm{x}, \mathrm{y}, 3 / 2-\mathrm{z}$. 
The bidentate BPE ligands bridge translated metal centers along the [001] direction, thus connecting adjacent $[\mathrm{Cd}(\mathrm{HBTC})]_{\mathrm{n}}$ layers to afford a 3D open framework (Figure 2). The BPE ligand adopts an anti-conformation $\left(\mathrm{C}-\mathrm{CH}_{2}-\mathrm{CH}_{2}-\mathrm{C}\right.$ torsion angle of $\left.180^{\circ}\right)$, however the pyridyl rings are nearly perpendicular to each other (interplanar angle being $72.48^{\circ}$ ). The $\mathrm{Cd}-$ --Cd separation across the BPE ligand is $13.863 \AA$. It may be regarded as a pillar of the $[\mathrm{Cd}(\mathrm{HBTC})]_{\mathrm{n}}$ layers through trans-coordination.

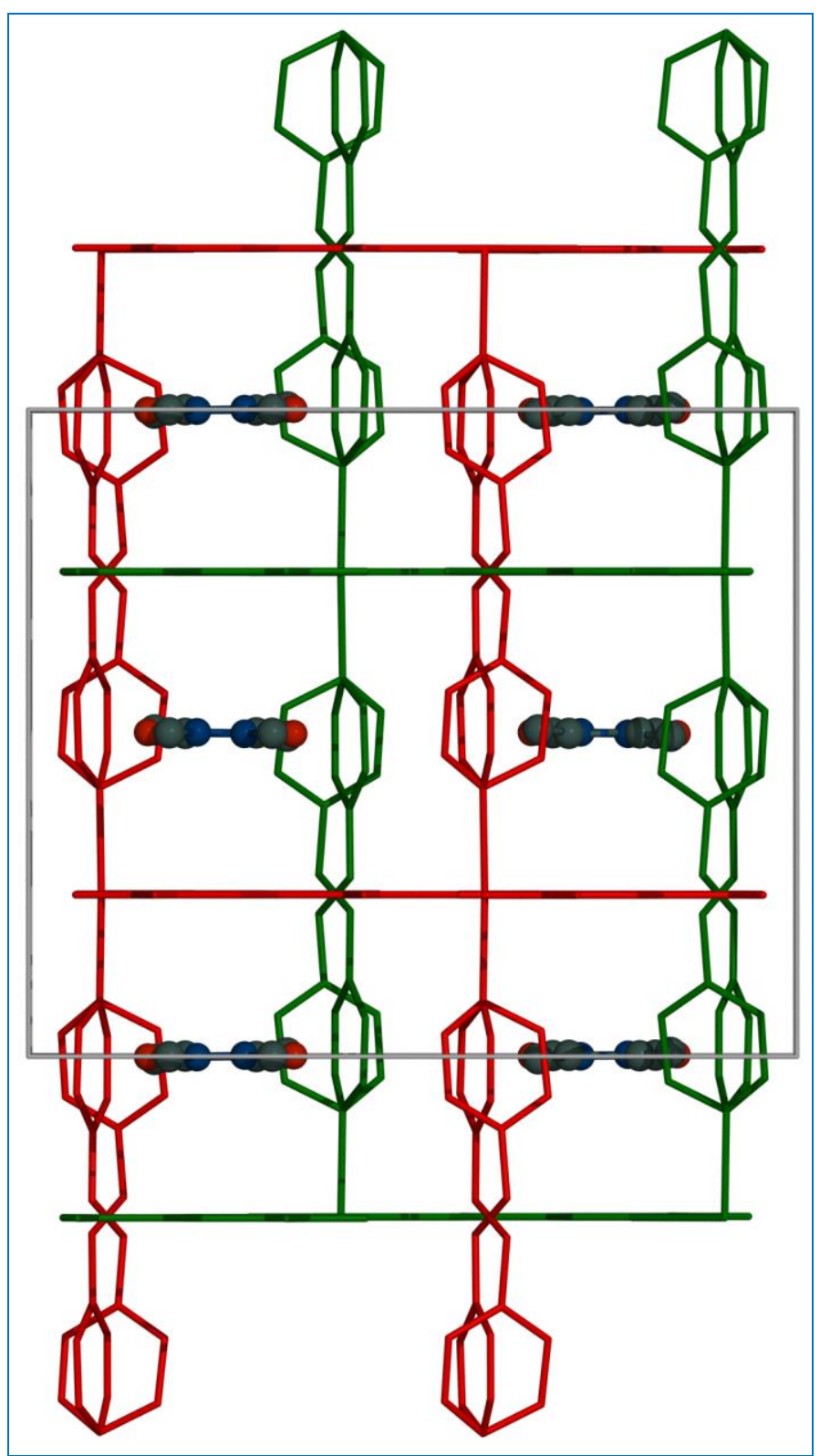

Figure 2. View down the $a$-axis showing the 2-fold interpenetrated pillared network (individual frameworks are depicted in red and green respectively) of $\mathbf{1}$. 
Table 1. Crystal data and structure refinement for 1, 2 and 3.

\begin{tabular}{|c|c|c|c|}
\hline & 1 & 2 & 3 \\
\hline Empirical formula & $\mathrm{C}_{24} \mathrm{H}_{23} \mathrm{Cd}_{1} \mathrm{~N}_{3} \mathrm{O}_{7}$ & $\mathrm{C}_{21} \mathrm{H}_{16} \mathrm{CdN}_{2} \mathrm{O}_{6}$ & $\mathrm{C}_{21} \mathrm{H}_{16} \mathrm{CdN}_{2} \mathrm{O}_{6}$ \\
\hline Formula weight & 577.85 & 504.77 & 504.77 \\
\hline Temperature $(\mathrm{K})$ & $173(2)$ & $173(2)$ & 173(2) \\
\hline$\lambda(\AA)$ & 0.71073 & 0.71073 & 0.71073 \\
\hline Crystal system & Orthorhombic & Orthorhombic & Orthorhombic \\
\hline Space group & $\mathrm{Pbcm}$ & Pbca & Pbcm \\
\hline Unit cell dimensions $(\AA)$ & $a=10.4621(10)$ & $a=16.811(3)$ & $a=10.3913(8)$ \\
\hline & $b=16.6080(15)$ & $b=13.891(3)$ & $\mathrm{b}=16.7981(13)$ \\
\hline & $\mathrm{c}=13.9436(13)$ & $c=20.743(4)$ & $\mathrm{c}=13.8612(11)$ \\
\hline Volume $\left(\AA^{3}\right)$ & $2422.8(4)$ & $4843.9(17)$ & $2419.5(3)$ \\
\hline$Z$ & 4 & 8 & 4 \\
\hline Calc. density $\left(\mathrm{gcm}^{-3}\right)$ & 1.587 & 1.387 & 1.386 \\
\hline$\mu\left(\mathrm{mm}^{-1}\right)$ & 0.951 & 0.936 & 0.937 \\
\hline$F_{000}$ & 1172 & 2024 & 1008 \\
\hline Crystal size $\left(\mathrm{mm}^{3}\right)$ & $0.20 \times 0.15 \times 0.10$ & $0.21 \times 0.18 \times 0.14$ & $0.20 \times 0.15 \times 0.10$ \\
\hline $\begin{array}{l}\theta \text { range for data } \\
\text { collection }\left(^{\circ}\right)\end{array}$ & $1.95-25.00$ & $2.83-25.00$ & $1.96-24.99$ \\
\hline Miller index ranges & $\begin{array}{l}-12 \leq h \leq 8,-19 \leq k \\
\leq 11,-16 \leq l \leq 16\end{array}$ & $\begin{array}{l}-19 \leq h \leq 19,-16 \leq k \\
\leq 16,-24 \leq l \leq 24\end{array}$ & $\begin{array}{l}-12 \leq h \leq 11,-19 \leq k \\
\leq 19,-16 \leq l \leq 16\end{array}$ \\
\hline Reflections collected & 10409 & 77879 & 9491 \\
\hline Independent reflections & $2224\left[R_{\mathrm{int}}=0.0516\right]$ & $4255\left[R_{\mathrm{int}}=0.0622\right]$ & $2204\left[R_{\text {int }}=0.0298\right]$ \\
\hline Completeness to $\theta_{\max }(\%)$ & 99.3 & 99.7 & 98.6 \\
\hline $\begin{array}{l}\text { Max. and min. } \\
\text { transmission }\end{array}$ & 0.91 and 0.83 & 0.88 and 0.83 & 0.91 and 0.84 \\
\hline Refinement method & $\begin{array}{l}\text { Full-matrix least- } \\
\text { squares on } F^{2}\end{array}$ & $\begin{array}{l}\text { Full-matrix least- } \\
\text { squares on } F^{2}\end{array}$ & $\begin{array}{l}\text { Full-matrix least- } \\
\text { squares on } F^{2}\end{array}$ \\
\hline $\begin{array}{l}\text { Data / restraints / } \\
\text { parameters }\end{array}$ & 2224 / 7 / 238 & 4255 / 0 / 272 & 2204 / 18 / 211 \\
\hline Goodness-of-fit on $F^{2}$ & 1.255 & 1.042 & 1.129 \\
\hline $\begin{array}{l}\text { Final } R \text { indices }[I>2 \sigma \\
(I D]\end{array}$ & $\begin{array}{l}R_{1}=0.0510, \mathrm{w} R_{2}= \\
0.1557\end{array}$ & $\begin{array}{l}R_{1}=0.0300, w R_{2}= \\
0.0745\end{array}$ & $\begin{array}{l}R_{1}=0.0499, w R_{2}= \\
0.1283\end{array}$ \\
\hline $\mathrm{R}$ indices (all data) & $\begin{array}{l}R_{1}=0.0651, \mathrm{w} R_{2}= \\
0.1639\end{array}$ & $\begin{array}{l}R_{1}=0.0437, w R_{2}= \\
0.0808\end{array}$ & $\begin{array}{l}R_{1}=0.0601, w R_{2}= \\
0.1344\end{array}$ \\
\hline $\begin{array}{l}\text { Largest diff. peak and } \\
\text { hole }\left(\mathrm{e} \AA^{-3}\right)\end{array}$ & 1.089 and -0.877 & 1.076 and -0.459 & 1.160 and -0.884 \\
\hline
\end{tabular}

The non-nitrogen atoms of the BPE ligands are disordered over two positions with site occupancy factors of $50 \%$ as required by a crystallographic mirror plane across which the molecule is located (the mirror plane is perpendicular to the long axis of the molecule). The DMF molecule is uncoordinated and disordered over two positions with site occupancy factors of 50\%. All bond distances of the DMF molecule were restrained to ideal values as unrestrained refinement lead to unacceptable bond distances and angles. A two-fold rotation axis $(x, 1 / 2-y,-z)$ with direction $[100]$ at $[x, 1 / 4,0]$ passes through the centre of the DMF molecule which relates one disordered position to the other. The structural analysis revealed 
the $[\mathrm{Cd}(\mathrm{HBTC})]_{\mathrm{n}}$ layers are positioned on mirror planes perpendicular to [001]. The cadmium and the trimesate ligand act as 3-connecting linkers in the $a b$-plane, so overall adopts 2dimensional sheet structure which further extend in the third dimension via the $\mathrm{Cd}^{2+}$ ions using BPE linkers as shown in Figure 2. The structure comprises of a two-fold interpenetrated network with cavities containing one DMF molecule each (Figure 2). A short, strong hydrogen bond reinforces the monodentate coordination mode of the two carboxylic

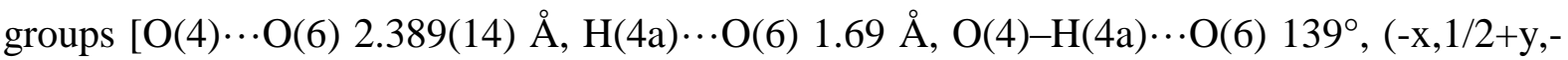
1/2-z)] forming 8-membered ring involving $\mathrm{Cd} 1$. The interpenetrated frameworks interact through $\mathrm{C}-\mathrm{H} \cdots \mathrm{O}$ interactions $[\mathrm{C}(15) \cdots \mathrm{O}(1) 3.29(2) \AA, \mathrm{H}(15 \mathrm{~B}) \cdots \mathrm{O}(1) 2.46 \AA, \mathrm{C}(15)-$ $\left.\mathrm{H}(15 \mathrm{~B}) \cdots \mathrm{O}(1) 141^{\circ},(1-\mathrm{x},-\mathrm{y}, 1 / 2+\mathrm{z})\right]$ and $[\mathrm{C}(16) \cdots \mathrm{O}(4) 3.395(18) \AA, \mathrm{H}(16 \mathrm{~B}) \cdots \mathrm{O}(4) 2.43 \AA$, $\left.\mathrm{C}(16)-\mathrm{H}(16 \mathrm{~B}) \cdots \mathrm{O}(4) 164^{\circ},(1+\mathrm{x}, 1 / 2-\mathrm{y},-\mathrm{z})\right]$ (Figure 5a) between the BPE ethylene hydrogen atoms and the oxygen atoms of the $\mathrm{HBTC}^{2-}$ anions, respectively.

\section{Structure of 2}

When single crystals of $\mathbf{1}$ were heated at $300{ }^{\circ} \mathrm{C}$ under vacuum for $5 \mathrm{~h}$, SC-SC transformation of $\mathbf{1}$ into the desolvated form $\mathbf{2}$, was observed. Structure elucidation by single crystal X-ray diffraction of $\mathbf{2}$ confirms that the framework structure and packing mode of $\mathbf{1}$ are retained and that the space previously occupied by DMF molecules becomes devoid of any appreciable electron density (Figure S1 and Figure 3). This was further confirmed by TG analysis with no appreciable mass loss occurring for $\mathbf{2}$ over the temperature range of 25-300 ${ }^{\circ} \mathrm{C}$. Crystallographic data, selected bond lengths and bond angles are listed in Tables 1,2 \& $\mathrm{S} 1$. The transformation from $\mathbf{1}$ to $\mathbf{2}$ involves changes in space group symmetry (from $\mathrm{Pbcm}$ to $P b c a$ ) but in effect amounts to similar lattice parameters (although axis $\sim 10 \AA$ doubles to $\sim 20$ $\AA$ ) and molecular stacking arrangements. Despite the close similarity in unit cell parameters of $\mathbf{1}$ and $\mathbf{2}$, the structures are indeed different as unequivocally demonstrated by the diffraction data, i.e. it's not possible to index $\mathbf{1}$ with the same unit cell as $\mathbf{2}$.

The asymmetric unit of 2 consists of one Cd(II), one HBTC ${ }^{2-}$ anion and one BPE molecule. The coordination environment of $\mathrm{Cd}(1)$ and the connectivity is the same as in the parent molecule (Figure 1). The average $\mathrm{Cd}-\mathrm{O}$ bond distance of $2.354 \AA$ is longer than parent molecule $(2.331 \AA)$ whilst the $\mathrm{Cd}-\mathrm{N}$ bond distance of $2.292 \AA$ is smaller than that of the

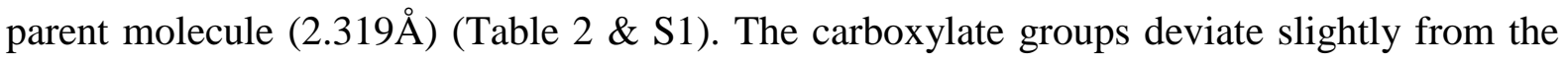
plane of the corresponding linking phenyl ring. The $\mathrm{Cd}---\mathrm{Cd}$ separation across the parallelogram-like sheets [Cd(HBTC) ]n being 10.379 (10.462 $\AA$ in 1) and $9.386 \AA$ (9.364 in 1) along $c$ and $a$-axis, respectively. As in the case of $\mathbf{1}$, strong hydrogen bonds reinforce 
the monodentate coordination mode of the carboxylic group $[\mathrm{O}(2)-\mathrm{H}(2)---\mathrm{O}(6)]$ forming 8membered ring each involving Cd1 (Table 3).

Table 2. Bond lengths $[\AA]$ for $\mathbf{1}, 2$ and $\mathbf{3}$.

\begin{tabular}{|c|c|c|c|c|c|}
\hline \multicolumn{2}{|c|}{$(\mathbf{1})$} & \multicolumn{2}{|c|}{$(2)$} & \multicolumn{2}{|r|}{ (3) } \\
\hline $\mathrm{Cd}(1)-\mathrm{O}(1)$ & $2.297(6)$ & $\mathrm{N}(1)-\mathrm{Cd}(1)$ & $2.290(3)$ & $\mathrm{Cd}(1)-\mathrm{O}(1)$ & $2.391(5)$ \\
\hline $\mathrm{Cd}(1)-\mathrm{O}(3) \# 1$ & $2.298(7)$ & $\mathrm{N}(2)-\mathrm{Cd}(1) \# 2$ & $2.294(3)$ & $\mathrm{Cd}(1)-\mathrm{O}(2)$ & $2.346(6)$ \\
\hline $\mathrm{Cd}(1)-\mathrm{O}(5) \# 2$ & $2.315(6)$ & $\mathrm{O}(1)-\mathrm{Cd}(1)$ & $2.265(2)$ & $\mathrm{Cd}(1)-\mathrm{O}(4) \# 1$ & $2.289(7)$ \\
\hline $\mathrm{Cd}(1)-\mathrm{N}(1)$ & $2.319(7)$ & $\mathrm{O}(3)-\mathrm{Cd}(1) \# 1$ & $2.364(2)$ & $\mathrm{Cd}(1)-\mathrm{O}(6) \# 4$ & $2.374(6)$ \\
\hline $\mathrm{Cd}(1)-\mathrm{O}(2)$ & $2.417(6)$ & $\mathrm{O}(4)-\mathrm{Cd}(1) \# 1$ & $2.384(2)$ & $\mathrm{Cd}(1)-\mathrm{N}(10)$ & $2.293(5)$ \\
\hline $\mathrm{O}(1)-\mathrm{C}(1)$ & $1.258(10)$ & $\mathrm{O}(5)-\mathrm{Cd}(1) \# 3$ & $2.400(2)$ & $\mathrm{O}(1)-\mathrm{C}(1)$ & $1.255(9)$ \\
\hline $\mathrm{C}(1)-\mathrm{O}(2)$ & $1.242(10)$ & $\mathrm{C}(1)-\mathrm{O}(1)$ & $1.247(4)$ & $\mathrm{C}(1)-\mathrm{O}(2)$ & $1.266(9)$ \\
\hline $\mathrm{O}(3)-\mathrm{C}(5)$ & $1.201(10)$ & $\mathrm{C}(1)-\mathrm{O}(2)$ & $1.256(4)$ & $\mathrm{O}(3)-\mathrm{C}(9)$ & $1.283(15)$ \\
\hline $\mathrm{O}(4)-\mathrm{C}(5)$ & $1.255(12)$ & $\mathrm{C}(8)-\mathrm{O}(4)$ & $1.252(4)$ & $\mathrm{O}(4)-\mathrm{C}(9)$ & $1.209(12)$ \\
\hline $\mathrm{O}(5)-\mathrm{C}(8)$ & $1.196(10)$ & $\mathrm{C}(8)-\mathrm{O}(3)$ & $1.265(3)$ & $\mathrm{O}(5)-\mathrm{C}(8)$ & $1.288(12)$ \\
\hline $\mathrm{O}(6)-\mathrm{C}(8)$ & $1.274(12)$ & $\mathrm{C}(9)-\mathrm{O}(5)$ & $1.217(4)$ & $\mathrm{O}(6)-\mathrm{C}(8)$ & $1.177(11)$ \\
\hline & & $\mathrm{C}(9)-\mathrm{O}(6)$ & $1.293(4)$ & & \\
\hline \multicolumn{6}{|c|}{ Symmetry transformations used to generate equivalent atoms: } \\
\hline \multirow{2}{*}{\multicolumn{2}{|c|}{\begin{tabular}{|l}
$\# 1-\mathrm{x}+1, \mathrm{y}+1 / 2, \mathrm{z}$ \\
$\# 2 \mathrm{x}+1, \mathrm{y}, \mathrm{z}$ \\
\end{tabular}}} & \multicolumn{4}{|c|}{$\# 1 \mathrm{x},-\mathrm{y}+3 / 2, \mathrm{z}-1 / 2 \quad \# 2 \mathrm{x}, \mathrm{y}-1, \mathrm{z} \# 1 \mathrm{x}+1, \mathrm{y},-\mathrm{z}+1 / 2$} \\
\hline & & $\# 3 x+1 / 2,-y+3$ & $/ 2,-\mathrm{Z}$ & $\# 4-x+2, y-1 / 2$ & \\
\hline
\end{tabular}

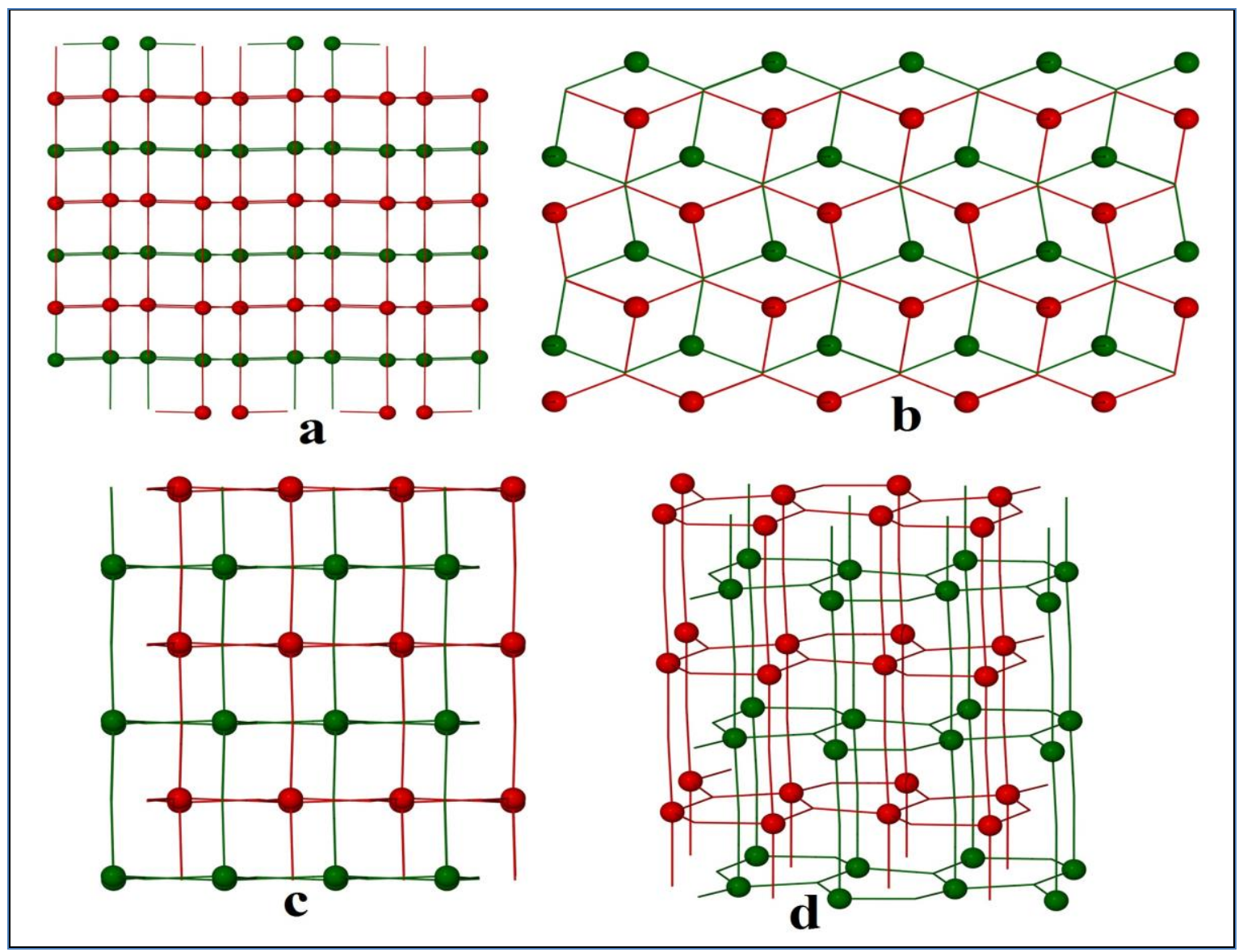

Figure 3. Views of the 2-fold-interpenetrated 3D topological network for $\mathbf{2}$ constructed from two identical hexagonal nets viewed down the (a) $a$-axis, (b) $b$-axis, (c) $c$-axis. (d) $h m s$ topology network displaying hexagonal packing. 
The following description of the network topology of $\mathbf{2}$ is applicable to that of $\mathbf{1}$ as well (crystallographic axes labels are different in $\mathbf{1}$ and 2). Each $\mathrm{Cd}(\mathrm{II})$ center serves as a 5connected node by linking to three HBTC $^{2-}$ anions with the vertex symbol of $\left(6.6 \cdot 6 \cdot 6_{2} \cdot 6_{2} \cdot 6_{2} \cdot 6_{2} \cdot 6_{2} \cdot 6_{2} \cdot 8_{6}\right)$, and each $\mathrm{HBTC}^{2-}$ anion represents a 3-connected node by linking to three $\mathrm{Cd}(\mathrm{II})$ with the vertex symbol of $\left(6_{3} \cdot 6_{3} \cdot 6_{3}\right)$ to generate sheets parallel to the $a c$-plane, which in turn are connected in the third dimension by BPE ligands. The sheets feature a honeycomb-like layer with topological representation of $6^{3}$. Thus, a 3-D (3,5)-connected network with the Schläfli symbol of $\left\{6^{\wedge} 3\right\}\left\{6^{\wedge} 9.8\right\}$ VS[6.6.6.6(2).6(2).6(2).6(2).6(2).6(2).*][6(3).6(3).6(3)] is generated with doubly interpenetrated (3,5)-connected $h m s$ topology ${ }^{29}$ as depicted in Figure 3. As in the case of 1, the interpenetrated frameworks interact through $\mathrm{C}-\mathrm{H}---\mathrm{O}$ interactions (Figure $4 \mathrm{~b}$ ) between the ethylene $\mathrm{H} 15 \mathrm{~b}$ and $\mathrm{H} 16 \mathrm{~b}$ to $\mathrm{O} 3$ and $\mathrm{O} 6$ and phenyl $\mathrm{C}-\mathrm{H}(\mathrm{H} 18$ and $\mathrm{H} 21)$ to $\mathrm{O} 4$ and $\mathrm{O} 2$ of carboxylic groups, respectively, which may be responsible for the structural stability of 2 .

Table 3. Hydrogen bonds in compound 2.

\begin{tabular}{|c|c|c|c|c|}
\hline Donor---H $\cdots$ Acceptor & Symmetry equivalent positions & $\mathrm{H} \cdots \mathrm{A}$ & $\mathrm{D} \cdots \mathrm{A}$ & $\mathrm{D}-\mathrm{H} \cdots \mathrm{A}$ \\
\hline $\mathrm{O}(2)-\mathrm{H}(2) \cdots \mathrm{O}(6)$ & {$[1 / 2+\mathrm{x}, 1 / 2-\mathrm{y},-\mathrm{z}]$} & 2.15 & 2.468 & 103 \\
\hline $\mathrm{C}(15)-\mathrm{H}(15 \mathrm{~B}) \cdots \mathrm{O}(3)$ & {$[1-\mathrm{x},-\mathrm{y},-\mathrm{z}]$} & 2.36 & 3.3145 & 161 \\
\hline $\mathrm{C}(16)-\mathrm{H}(16 \mathrm{~B}) \cdots \mathrm{O}(6)$ & {$[1 / 2-\mathrm{x},-1 / 2+\mathrm{y}, \mathrm{z}]$} & 2.47 & 3.3639 & 150 \\
\hline $\mathrm{C}(18)-\mathrm{H}(18) \cdots \mathrm{O}(4)$ & {$[1 / 2-x,-y, 1 / 2+z]$} & 2.58 & 3.4723 & 156 \\
\hline $\mathrm{C}(21)-\mathrm{H}(21) \cdots \mathrm{O}(2)$ & {$[1-\mathrm{x},-\mathrm{y},-\mathrm{z}]$} & 2.59 & 3.5217 & 166 \\
\hline
\end{tabular}

Two fold interpenetration leads to the disappearance of the big channels of the individual frameworks, and to the subsequent formation of small cavities formed by the HBTC $^{2-}$ anion and BPE ligands of both frameworks. In $\mathbf{1}$ these cavities are isolated, have a size of $158 \AA^{3}$ and are occupied by a single DMF molecule (Figure 4a). The desolvation of $\mathbf{1}$ upon heating must thus involve cooperative conformational changes in the frameworks in order to allow for the evacuation of the DMF molecules with the retention of monocrystallinity. Interestingly, in 2 the cavity size effectively doubles to $328 \AA^{3}$ (Figure $4 \mathrm{~b}$ ) as a result of two neighboring pyridyl groups from different frameworks which "opens" and allows two neighboring cavities to "connect" as when compared to $\mathbf{1}$. The disorder in structure 1 prohibits this scenario of two parallel pyridyl rings as the other disordered component (as required by the mirror plane in 1) will put the neighboring pyridyl groups in 
too close proximity. This illustrates that neighboring pyridyl rings in $\mathbf{2}$ are rotated differently with respect to one another when compared to both disordered situations in $\mathbf{1}$, which further supports that the frameworks of $\mathbf{1}$ and $\mathbf{2}$ indeed have subtle differences, aiding our argument that the desolvation process may be described as a SC-SC transformation. ${ }^{30}$ The total potential solvent area volumes of $1311 \AA^{3}$ represents $27.1 \%$ of the unit cell volume for structure 2 (volumes were determined using PLATON with $1.2 \AA$ probe radius). ${ }^{23}$

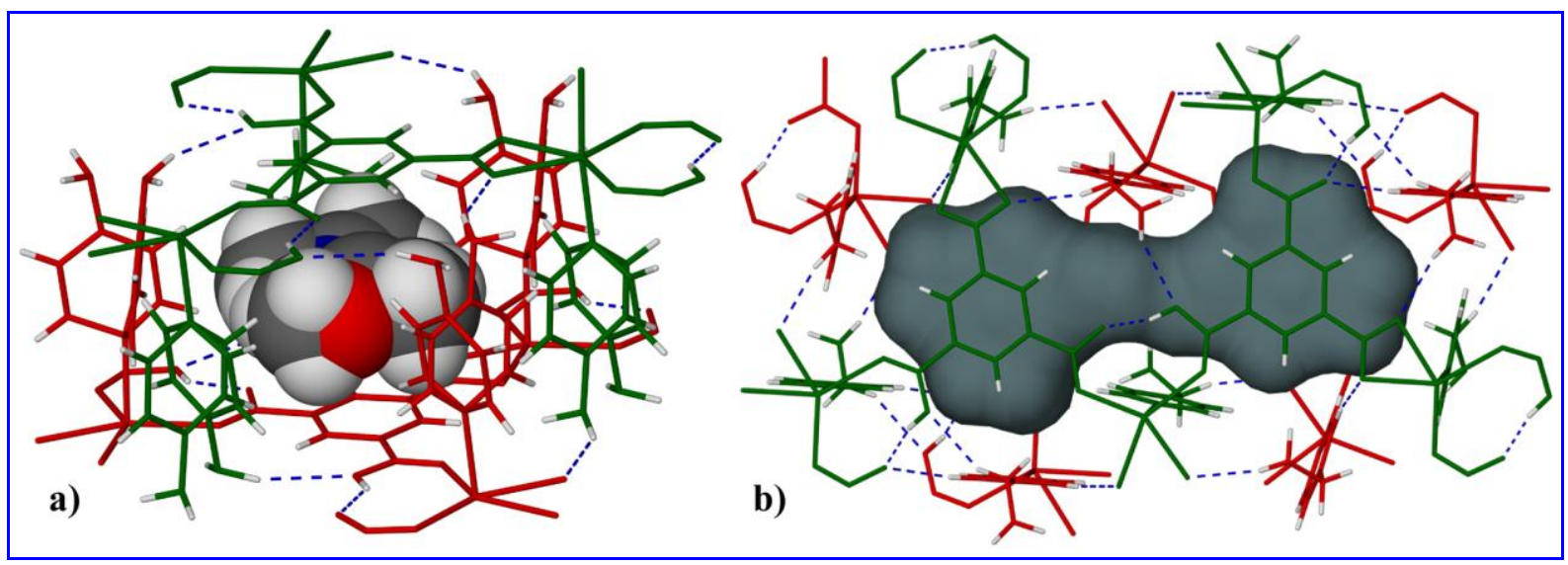

Figure 4. (a) A DMF molecule (displayed in space-filling mode) situated in a cavity of $\mathbf{1}$. Non-nitrogen atoms of the pyridyl rings are disordered over two positions with site occupancy factors of $50 \%$ (b) Cavity formed in 2 by the evacuation of DMF in $\mathbf{1}$. Two-fold interpenetrated networks (3,5-connected $h m s$ topology) are shown in red and green for both $\mathbf{1}$ and 2 and $\mathrm{C}-\mathrm{H} \cdots \mathrm{O}$ and $\mathrm{O}-\mathrm{H} \cdots \mathrm{O}$ interactions between the frameworks are shown for $\mathbf{2}$ (also present in 1).

\section{Structure of 3}

When single crystals of $\mathbf{2}$ were soaked in benzene overnight, SC-SC transformation of $\mathbf{2}$ to solvated compound $\mathbf{3}$ (2·benzene), was observed. Single crystal X-ray diffraction of $\mathbf{3}$ confirms that the framework structure and packing mode are retained but the unit cell values similar to 1. Crystallographic data, selected bond lengths and bond angles are listed in Tables $1,2 \& \mathrm{~S} 1$.

Due to disorder within the structure, we were only able to observe some electron density within the pores of $\mathbf{3}$ by single crystal X-ray diffraction, but were not able to assign specific atom positions for the benzene molecule. ${ }^{31}$ Despite the presence of benzene molecule (1:1 ratio) being confirmed by TG.

\section{Single Crystal - Single Crystal Transformation triggered by thermal treatment}


Powder X-ray diffraction (PXRD) was used to check the structural identity and possible phase transition of $\mathbf{1}$ into $\mathbf{2}$. Due to the close similarity of the crystal structures of $\mathbf{1}$ and $\mathbf{2}$ it is not surprising that their calculated powder patterns are virtually identical. However significant differences do exist as illustrated in Figure 6.

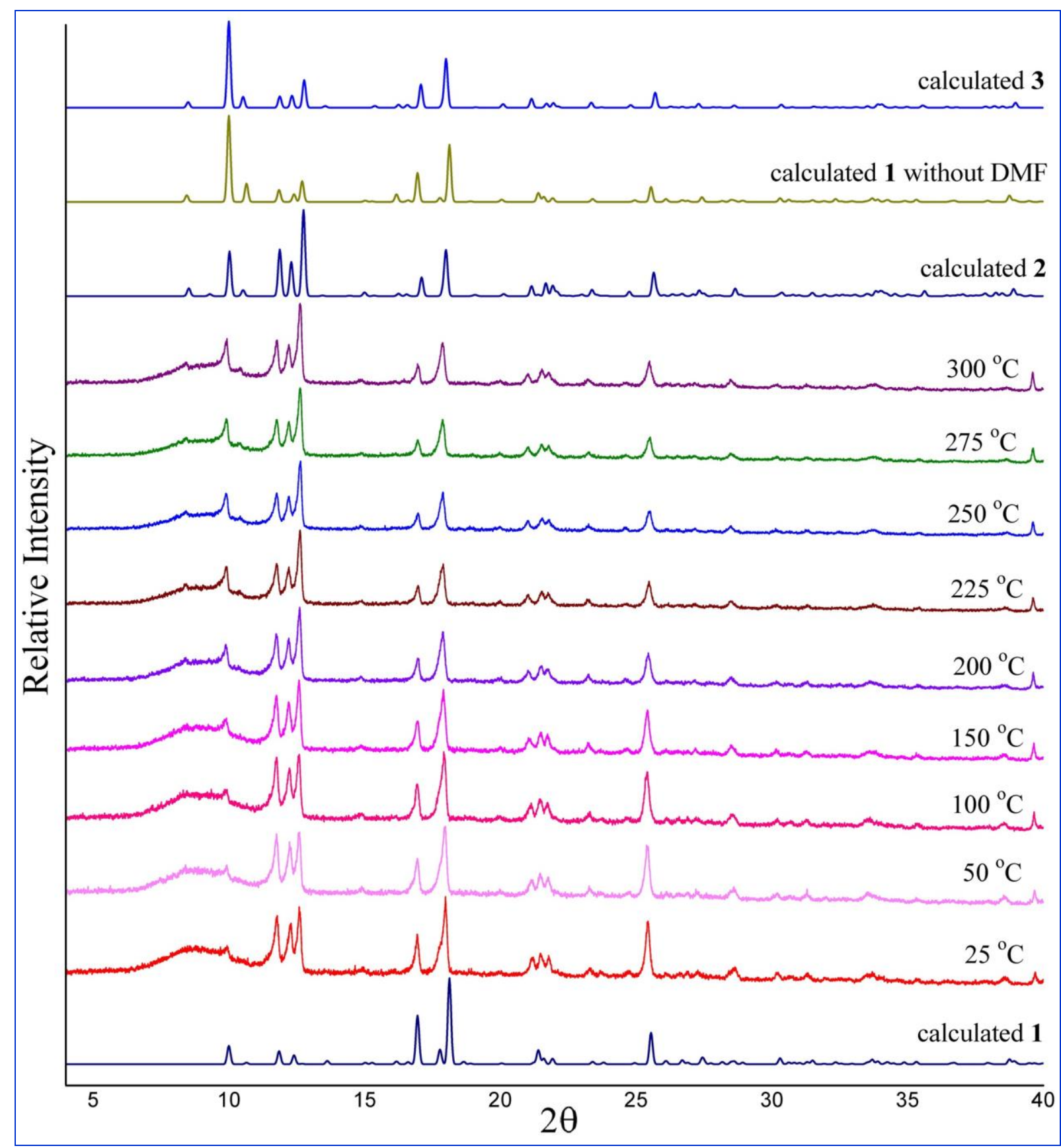

Figure 6. PXRD pattern at variable temperature and compared with the calculated patterns of 1,2 and 3.

The room temperature PXRD pattern of 1 closely resembles that of the calculated pattern, however the three peaks at $11-13^{\circ} 2 \theta$ resemble that of the calculated pattern of 2 , which perhaps indicates that some of the sample may already have desolvated when the 
analysis commenced. Despite repeated attempts we could not obtain an experimental pattern of different samples of $\mathbf{1}$ which resembles that of the calculated PXRD pattern more closely. We do however observe a general trend of the experimental PXRD pattern of 1 to resemble that of the calculated pattern of $\mathbf{2}$ with increasing temperature. For example, the shoulder at $2 \theta=17^{\circ}$ starts disappearing, the peaks at $2 \theta=10-13^{\circ}$ increase in relative intensity to the peak at $2 \theta=17^{\circ}$, whilst the peaks at $2 \theta=25.6-27.5^{\circ}$ separate. More importantly, PXRD measurements at variable temperatures illustrated the robustness of the framework upon removal of DMF molecules and up to $300^{\circ} \mathrm{C}$. The patterns calculated from the crystal structure of $\mathbf{3}$ and calculated from that of $\mathbf{1}$ (DMF coordinates omitted) are also included in Figure 6 for reference.

\section{TGA}

The TGA data of complex 1 indicates two mass losses (Figure S2). The first mass loss $115-350{ }^{\circ} \mathrm{C}(13.2 \%)$ corresponds to the loss of half a DMF molecule per asymmetric unit (calculated: $12.6 \%)$. An abrupt mass loss in the range $360-480{ }^{\circ} \mathrm{C}(66.2 \%)$ corresponds to structure decomposition. DSC shows only one broad endotherm peak which should be due to the loss of DMF (Figure S2). Hot stage microscopy indicates visual loss of DMF occurs for 1 in the temperature range $270-280{ }^{\circ} \mathrm{C}$ (Figure 7). Visual observation of chloroform and benzene release (Figure 7) was also recorded for the crystals of $\mathbf{3}$ and $\mathbf{4}$ respectively, under the hot stage microscope by immersing the sample in silicone oil and heating to $300{ }^{\circ} \mathrm{C}$. Bubbles of chloroform and benzene were released in the range $90-110{ }^{\circ} \mathrm{C}$ and $160-170{ }^{\circ} \mathrm{C}$ respectively. The TGA analysis for 3 however, revealed a clear mass loss (12.3\%), between $160-170{ }^{\circ} \mathrm{C}$ (Figure S3).

\section{Sorption of organic solvents}

Due to the great stability of framework the uptake of different solvent molecules was analyzed. Therefore few crystals of $\mathbf{2}$ were immersed into the different solvents (DMF, ethanol, methanol, mesitylene, THF, $\mathrm{C}_{6} \mathrm{H}_{6}, \mathrm{CHCl}_{3}, \mathrm{CH}_{2} \mathrm{Cl}_{2}$, toluene and 1,4-dioxane) overnight and afterwards thermogravimetric analyses were performed (Figure S3 \&Table 3). Compound 2. solvent showed a prolonged weight loss in the range of $60-250{ }^{\circ} \mathrm{C}$ for benzene, $30-250{ }^{\circ} \mathrm{C}$ for $\mathrm{CHCl}_{3}, 30-100{ }^{\circ} \mathrm{C}$ THF and $30-215{ }^{\circ} \mathrm{C}$ for 1,4 -dioxane that amounted to 11.63 , 16.18, 12.34 and $16.79 \%$, respectively, (Table 4). The different profiles of the TGA suggest that the uptakes were not simply due to different amounts water absorbed in the event that the solvents used were wet. 
Table 4: Results of the solvent uptake experiment.

\begin{tabular}{|l|l|l|l|}
\hline Entry & 2.Solvent & \% Mass loss in TGA & \% Calculated mass loss* \\
\hline 1 & DMF & 3.02 & 12.6 \\
2 & EtOH & 0.1 & 8.3 \\
3 & MeOH & 0.6 & 5.9 \\
4 & mesitylene & 2.5 & 19.2 \\
5 & benzene & 11.63 & 13.3 \\
6 & chloroform & 16.18 & 19.1 \\
7 & toluene & 6.86 & 15.4 \\
8 & DCM & 10.44 & 14.3 \\
9 & $1,4-$ dioxane & 16.79 & 14.8 \\
10 & THF & 12.34 & 12.4 \\
\hline
\end{tabular}

*: calculated $\%$ mass loss for the case that every cavity is occupied by one solvent molecule. 


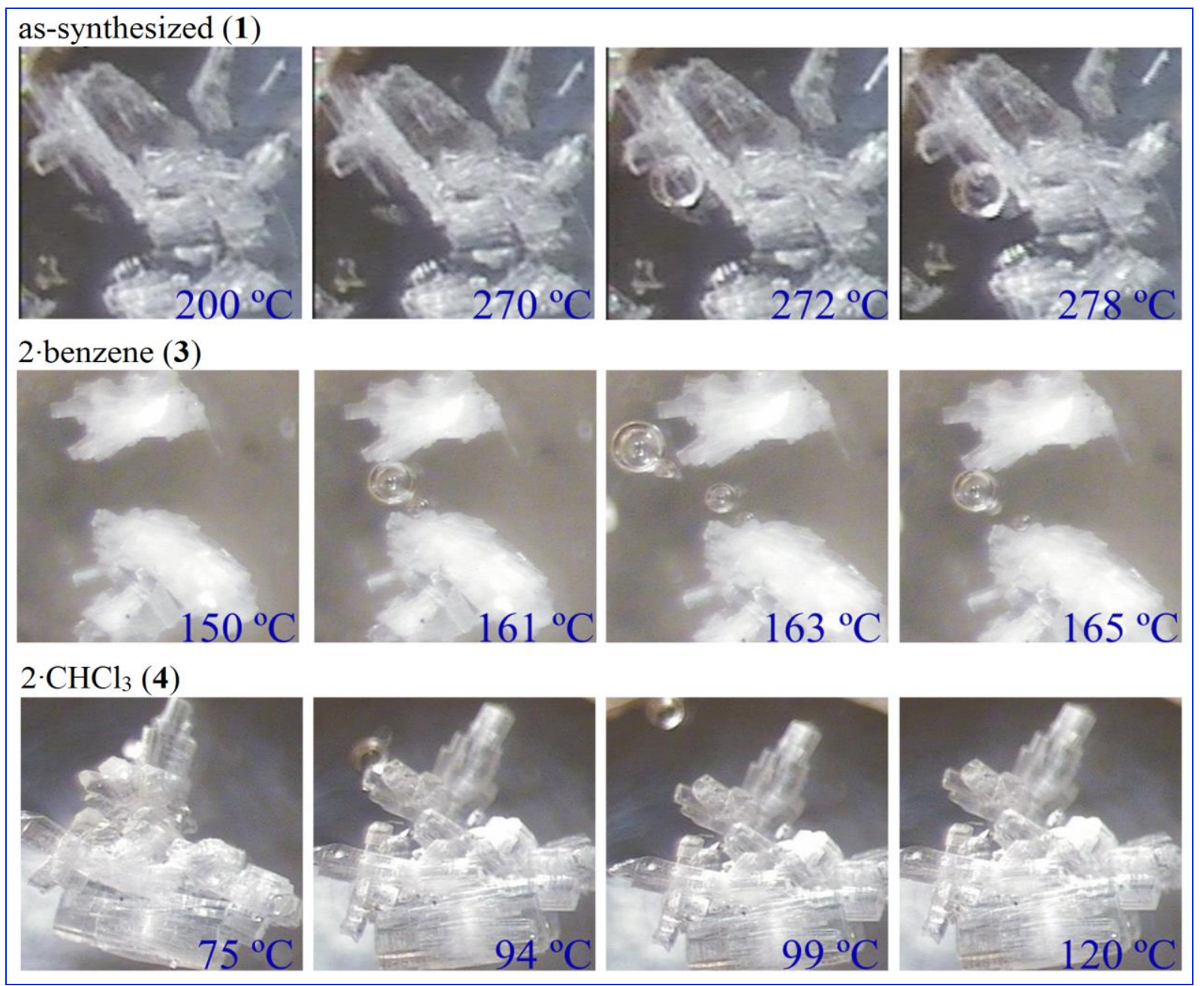

Figure 7. Hot stage microscope photographs of compounds $\mathbf{1}, \mathbf{2} \cdot$ benzene $(3)$ and $\mathbf{2} \cdot \mathbf{C H C l}_{\mathbf{3}}$ (4) to showing the release of solvents at various temperatures.

As shown in Table 4 there was a high selectivity for the benzene, chloroform, 1,4dioxane and THF, whereas it was not possible to resorb the DMF again to the same degree as for these solvents. Due to the higher affinity of the compound to some solvents than to DMF it was assumed that a guest exchange might also be possible. Hence some crystals of the assynthesized, DMF containing compound 1 were immersed in chloroform, $\mathrm{H}_{2} \mathrm{O}$, ethanol, methanol, benzene, dichloromethane, tetrahydrofuran and 1,4-dioxane for overnight and analyzed in TGA afterwards. However, the TGA spectrum only showed a mass loss (the same value as original) at the temperature range of $200-300{ }^{\circ} \mathrm{C}$ which is specific for the loss of the DMF and not for other solvents, which should occur at lower temperature. It was assumed that there was no guest exchange between the two solvents, which is remarkable because the structure seems to be having a higher affinity for nonpolar solvents than for DMF. This could be due to slight conformational difference in $1 \& 2$ change which allows passage of molecules in $\mathbf{2}$ whereas the release of DMF molecules in $\mathbf{1}$ requires heating to higher temperatures. In all cases, the sorption of the various organic solvents seemed to be 
SC-SC transformations as judged from visual observations as well as the ability to in each case determine unit cells using single crystal X-ray diffraction.

\section{Gas sorption}

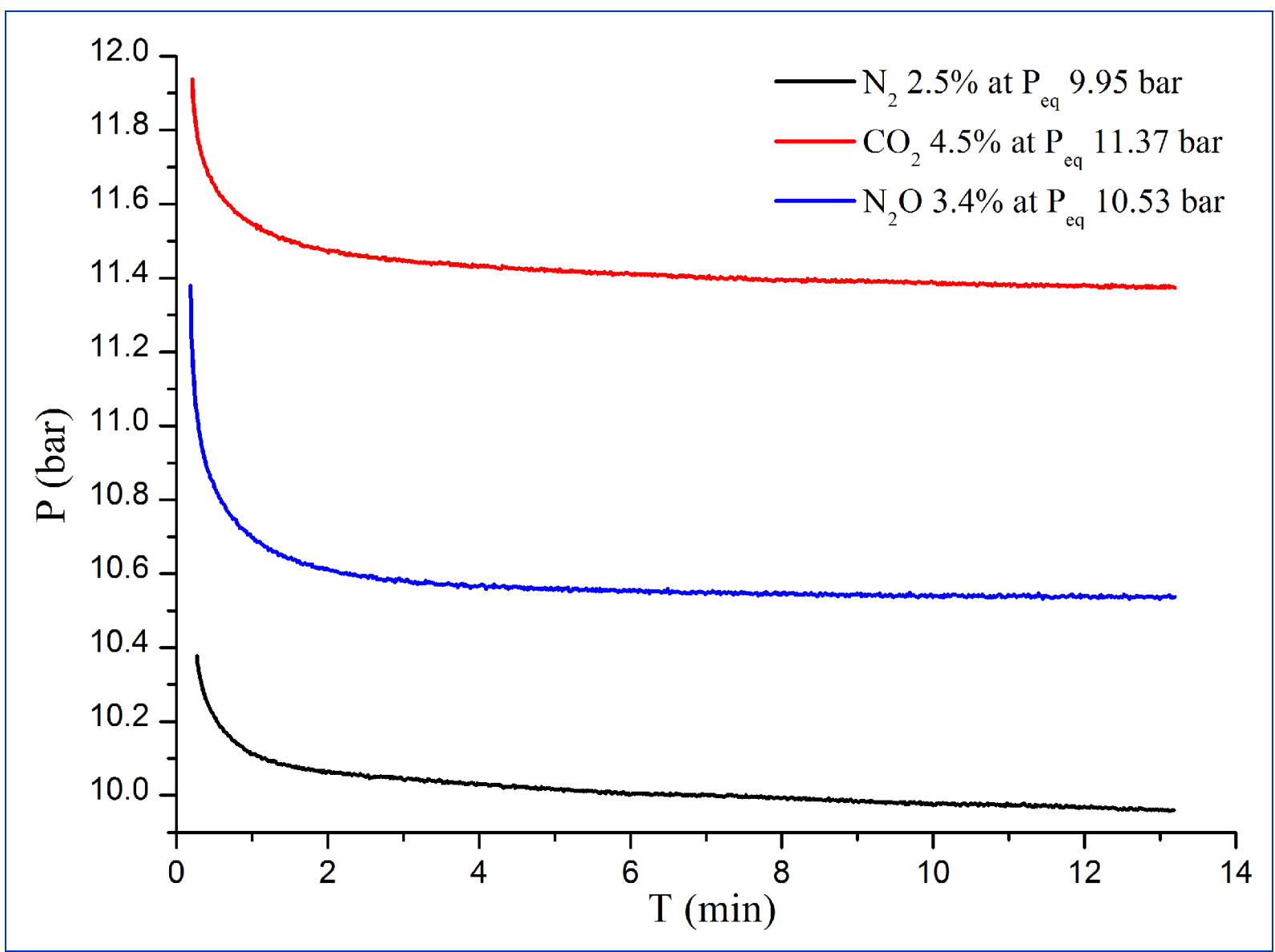

Figure 8. Gas sorption in $2\left(\mathrm{~N}_{2}\right.$ : black; $\mathrm{N}_{2} \mathrm{O}$ : blue; $\mathrm{CO}_{2}$ : red).

Due to the high total potential solvent area of $1311 \AA^{3}$ per unit cell volume or $27.1 \%$ for 2 gas sorption experiments were performed. The structure showed comparable sorption of $2.5 \% \mathrm{~N}_{2}, 4.5 \% \mathrm{CO}_{2}$ and $3.4 \% \mathrm{~N}_{2} \mathrm{O}$ absorption by mass at a pressure of 9-12 bar. The graphs of the gas sorption are shown in Figure 8, the sorption of $\mathrm{N}_{2}, \mathrm{CO}_{2}$ and $\mathrm{N}_{2} \mathrm{O}$ occur rapidly within the first few minutes of the analysis. Hydrogen sorption by $\mathbf{2}$ was negligible.

IR

The strong asymmetric $\left(v_{\mathrm{as}}\right)$ and symmetric vibrations $\left(v_{\mathrm{s}}\right)$ of the carboxylate groups are located at 1612, 1578, 1434 and $1369 \mathrm{~cm}^{-1}$ (Figure S4). The differences between $v_{\mathrm{as}}$ and $v_{\mathrm{S}}$ of $144 \mathrm{~cm}^{-1}$ and $243 \mathrm{~cm}^{-1}$ indicate bidentate and unidentate coordination mode of carboxylate group, which is also be confirmed by single-crystal structure determinations. ${ }^{32}$ There is a shoulder peak at $1673 \mathrm{~cm}^{-1}$, which indicates that there is protonated carboxyl group in the 
complex. Compared with the usual reports for protonated carboxyl group at $1720-1680 \mathrm{~cm}^{-1}$, this peak shifts to lower wave-number due to $\mathrm{H}$-bond interaction. ${ }^{33}$ Weak and broad absorption at $1739 \mathrm{~cm}^{-1}$ corresponds to DMF. IR spectrum for desolvated $\mathbf{2}$ was also recorded and found to be same except that of absorption at $1739 \mathrm{~cm}^{-1}$ which disappears.

\section{Conclusion}

In conclusion, a new 3-D MOF has been synthesized based on $\mathrm{Cd}\left(\mathrm{NO}_{3}\right)_{2}$, trimesic acid and 1,2-bis(4-pyridyl)ethane, which exhibits temperature-induced SC-SC transformation involving release of DMF molecules. The resulting desolvated form is highly stable up to 350 ${ }^{\circ} \mathrm{C}$ and exhibit single crystal to single crystal transformation in selected solvents (benzene, chloroform, 1,4-dioxane and THF molecules over other polar solvents). The desolvation and solvation processes must involve cooperative conformational changes in the structures in order to retain monocrystallinity. In addition, the solvated and desolvated states of the framework reveal structural differences which further supports describing the desolvation/solvation processes as single crystal to single crystal transformations. The solvent free porous framework shows a total potential solvent area of $27.1 \%$ of the structures volume. The structure showed $2.5 \% \mathrm{~N}_{2}, 4.5 \% \mathrm{CO}_{2}$ and $3.4 \% \mathrm{~N}_{2} \mathrm{O}$ absorption by mass. Studies are underway in our laboratory to further explore the robustness of this MOF system and to explain the selectivity of the sorption of the investigated solvents and gases.

\section{Acknowledgment}

AH and CLO thank the South African National Research Foundation and the University of Cape Town for financial support.

Supporting Information Available: Figures S1-S4, TableS1 and X-ray crystallographic information files (CIF) are available for compounds 1-3. This material is available free of charge via the Internet at http://pubs.acs.org.

\section{References}

1. (a) Zhao, D.; Yuan, D.; Zhou, H.-C. Energy Environ. Sci. 2008, 1, 222-235; (b) Sculley, J.; Yuan, D.; Zhou, H.-C. Energy Environ. Sci. 2011, 4, 2721-2735; (c) Murray, L. J.; Dinca, M.; Long, J. R. Chem. Soc. Rev. 2009, 38, 1294-1314; (d) Hirscher, M. Angew. Chem. Int. Ed. 2011, 50, 581-582; (e) Ma, S.; Zhou, H.-C. 
Chem. Commun. 2010, 46, 44-53; (f) Zhou, W. Chem. Rec. 2010, 10, 200-204; (g) D’Alessandro, D. M.; Smit, B.; Long, J. R. Angew. Chem. Int. Ed. 2010, 49, 60586082; (h) Li, J.-R.; Kuppler, R. J.; Zhou, H.-C. Chem. Soc. Rev. 2009, 38, 1477-1504; (i) Li, J.-R.; Ma, Y.; McCarthy, M. C.; Sculley, J.; Yu, J.; Jeong, H.-K.; Balbuena, P. B.; Zhou, H.-C. Coord. Chem. Rev. 2011, 255, 1791-1823; (j) Lu, W.; Yuan, D.; Makal, T. A.; Li, J.-R.; Zhou, H.-C. Angew. Chem. Int. Ed. 2012, 51, 1580-1584.

2. (a) Eddaoudi, M.; Li, H.; Yaghi, O. M. J. Am. Chem. Soc. 2000, 122, 1391-1397; (b) Yaghi, O. M.; Li, H.; Groy, T. L. J. Am. Chem. Soc. 1996, 118, 9096-9101; (c) Yaghi, O. M.; Davis, C. E.; Li, G.; Li, H. J. Am. Chem. Soc. 1997, 119, 2861-2868; (d) Fang, Q.; Zhu, G.; Xue, M.; Sun, J.; Sun, F.; Qiu, S. Inorg. Chem. 2006, 45, 3582-3587; (e) Yaghi, O. M.; Li, G.; Li, H. Nature 1995, 378, 703-706; (f) Eddaoudi, M.; Moler, D. B.; Li, H.; Chen, B.; Reineke, T. M.; O'Keeffe, M.; Yaghi, O. M. Acc. Chem. Res. 2001, 34, 319-330; (g) Chui, S. S.-Y.; Lo, S. M.-F.; Charmant, J. P. H.; Orpen, A. G.; Williams, I. D. Science 1999, 283, 1148-1150; (h) Plater, M. J.; Foreman, M. R. S. J.; Howie, R. A.; Skakle, J. M. S.; Coronado, E.; Gomez-Garcia, C. J.; Gelbrich, T.; Hursthouse, M. B. Inorg. Chim. Acta 2001, 319, 159-175; (j) Prior, T. J.; Rosseinsky, M. J. Chem. Commun. 2001, 1222-1223; (k) Sun, D.; Cao, R.; Weng, J.; Hong, M.; Liang, Y.; Dalton Trans. 2002, 291-292; (1) Dai, J.-C.; Wu, X.-T.; Fu, Z.-Y.; Cui, C.P.; Hu, S.-M.; Du, W.-X.; Wu, L.-M.; Zhang, H.-H.; Sun, R.-Q. Inorg. Chem. 2002, 41, 1391-1396. (m) Wu, G.; Shi, X.; Fang, Q.; Tian, G.; Wang, L.; Zhu, G.; Addison, A. W.; Wei, Y.; Qiu, S.; Inorg. Chem. Commun. 2003, 6, 402-404; (n) Zhu, H.-F.; Sun, W.-Y.; Okamura, T.-A.; Ueyama, N. Inorg. Chem. Commun. 2003, 6, 168-173; (o) Lu, Z.-L.; Chen, W.; Xu, J.-Q.; Zhang, L.-J.; Pan, C.-L.; Wang, T.-G. Inorg. Chem. Commun. 2003, 6, 244-248; (p) Chen, J.-X.; Liu, S.-X.; Gao, E.-Q. Polyhedron 2004, 23, 1877-1888.

3. (a) Hong, D.-Y.; Hwang, Y. K.; Serre, C.; Ferey, G.; Chang, J.-S. Adv. Funct. Mater. 2009, 19, 1537-1552; (b) Perry, J. J.; Perman, J. A.; Zaworotko, M. J. Chem. Soc. Rev. 2009, 38, 1400-1417; (c) Lin, X.; Telepeni, I.; Blake, A. J.; Dailly, A.; Brown, C. M.; Simmons, J. M.; Zoppi, M.; Walker, G. S.; Thomas, K. M.; Mays, T. J.; Hubberstey, P.; Champness, N. R.; Schroder, M. J. Am. Chem. Soc. 2009, 131, 21592171; (d) Nelson, A. P.; Farha, O. K.; Mulfort, K. L.; Hupp, J. T. J. Am. Chem. Soc. 2009, 131, 458-460. (e) Furukawa, H.; Ko, N.; Go, Y. B.; Aratani, N.; Choi, S. B.; Choi, E.; Yazaydin, A. O.; Snurr, R. Q.; O’Keeffe, M.; Kim, J.; Yaghi, O. M. Science 2010, 329, 424-428. (f) Farha, O. K.; Spokoyny, A. M.; Hauser, B. G.; Bae, Y.-S.; Brown, S. E.; Snurr, R. Q.; Mirkin, C. A.; Hupp, J. T. Chem. Mater. 2009, 21, 30333035. (h) Lin, Z.-J.; Liu, T.-F.; Xu, B.; Han, L.-W.; Huang, Y.-B.; Cao, R. Cryst. Eng. Comm. 2011, 13, 3321-3324. (i) Xue, Y.-S.; He, Y.; Ren, S.-B.; Yue, Y.; Zhou, L.; Li, Y.-Z.; Du, H.-B.; You, X.-Z.; Chen, B. J. Mater. Chem. 2012, 22, 10195-10199; (j) Zhuang, W.; Yuan, D.; Liu, D.; Zhong, C.; Li, J.-R.; Zhou, H.-C. Chem. Mater. 2012, $24,18-25$.

4. (a) Kitagawa, S.; Uemura, K. Chem. Soc. Rev. 2005, 34, 109-119; (b) Vittal, J. J. Coord. Chem. Rev. 2007, 251, 1781-1795; (c) Kawano, M.; Fujita, M. Coord. Chem. Rev. 2007, 251, 2592-2605.

5. (a) Biradha, K.; Fujita, M. Angew. Chem. Int. Ed. 2002, 41, 3392-3395; (b) Pretsch, T.; Chapman, K. W.; Halder, G. J.; Kepert, C. J. Chem. Commun. 2006, 1857-1859; (c) Bardelang, D.; Udachin, K. A.; Anedda, R.; Moudrakovski, I.; Leek, D. M.; Ripmeester, J. A.; Ratcliffe, C. I. Chem. Commun. 2008, 4927-4929. 
6. (a) Liu, D.; Ren, Z.-G.; Li, H.-X.; Lang, J.-P.; Li, N.-Y.; Abrahams, B. F. Angew. Chem. Int. Ed. 2010, 49, 4767-4770; (b) Mir, M. H.; Koh, L. L.; Tan, G. K.; Vittal, J. J. Angew. Chem. Int. Ed. 2010, 49, 390-393.

7. Sharma, M. K.; Bharadwaj, P. K. Inorg. Chem. 2011, 50, 1889-1897; (b) Massera, C.; Melegari, M.; Kalenius, E.; Ugozzoli, F.; Dalcanale, E. Chem. Eur. J. 2011, 17, 30643068; (c) Li, H.-X.; Ren, Z.-G.; Liu, D.; Chen, Y.; Lang, J.-P.; Cheng, Z.-P.; Zhu, X.L.; Abrahams, B. F. Chem. Commun. 2010, 46, 8430-8432.

8. Falkowski, J. M.; Wang, C.; Liu, S.; Lin, W. Angew. Chem. Int. Ed. 2011, 50, 86748678.

9. (a) Ghosh, S. K.; Kaneko, W.; Kiriya, D.; Ohba, M.; Kitagawa, S. Angew. Chem. Int. Ed. 2008, 47, 8843-8847; (b) Ghosh, S. K.; Zhang, J. -P.; Kitagawa, S. Angew. Chem. Int. Ed. 2007, 46, 7965-7968.

10. (a) Perles, J.; Iglesias, M.; Ruiz-Valero, C.; Snejko, N. Chem. Commun. 2003, 346347; (b) Perles, J.; Snejko, N.; Iglesias, M.; Monge, M. A. J. Mater. Chem. 2009, 19, 6504-6511.

11. Song, Y.-M.; Luo, F.; Luo, M.-B.; Liao, Z.-W.; Sun, G.-M.; Tian, X.-Z.; Zhu, Y.; Yuan, Z.-J.; Liu, S.-J.; Xu, W.-Y.; Feng, X.-F. Chem. Commun. 2012, 48, 1006-1008.

12. Bernini, M. C.; Gandara, F.; Iglesias, M.; Snejko, N.; Gutierrez-Puebla, E.; Brusau, E. V.; Narda, G. E.; Monge, M. A. Chem. Eur. J. 2009, 15, 4896-4905.

13. Cao, M.-L.; Mo, H.-J.; Liang, J.-J.; Ye, B.-H. Cryst. Eng. Comm. 2009, 11, 784-790.

14. Xue, D.-X.; Zhang, W.-X.; Chen, X.-M.; Wang, H.-Z. Chem. Commun. 2008, 15511553.

15. Paz, F. A. A.; Klinowski, J. Inorg. Chem. 2004, 43, 3948-3954.

16. Soft Imaging System GmbH: Digital solutions for Imaging and Microscopy, Version 3.1 for Windows, (C) 1987-2000.

17. SAINT-Plus, Version 7.12; Bruker AXS Inc.: Madison, WI, USA, 2004.

18. Bruker. XPREP2, Version 6.14; Bruker AXS Inc.: Madison, WI, USA, 2003.

19. Barbour, L. J. J. Appl. Cryst. 1999, 32, 351-352.

20. Otwinowski, Z.; Minor, W. In International Tables for Crystallography; Rossman, M. G., Arnold, E., Eds.; Kluwer: Dordrecht, 2000; Vol. F.

21. Sheldrick, G. M. SADABS; University of Gottingen: Germany, 1996.

22. Sheldrick, G. M. Acta Cryst. 2008, A64, 112-122.

23. Spek, A. L. J. Appl. Cryst. 2003, 36, 7-13.

24. Farrugia, L. J. J. Appl. Cryst. 1997, 30, 565-565.

25. Macrae, C. F.; Bruno, I. J.; Chisholm, J. A.; Edgington, P. R.; McCabe, P.; Pidcock, E.; Rodriguez-Monge, L.; Taylor, R.; van de Streek, J.; Wood, P. A. J. Appl. Cryst. 2008, 41, 466-470.

26. Yvon, K.; Jeitschko, W.; Parthé, E. J. Appl. Cryst. 1977, 10, 73-74.

27. (a) Atwood, J. L.; Barbour, L. J.; Thallapally, P. K.; Wirsig, T. B. Chem. Comm. 2005, 51-53; (b) Borel, C.; Davies, K.; Handa, P.; Hedberg, G.; Oliver, C. L.; Bourne, 
S. A.; Hakansson, M.; Langer, V.; Öhrström, L. Cryst. Growth Des. 2010, 10, 19711978.

28. Barbour, L. J. Absorbance Software, University of Stellenbosch: Stellenbosch, South Africa.

29. (a) Zhang, H.; Wang, F.; Kang, Y.; Zhang, J. Inorg. Chem. Commun. 2010, 13, 14291431; (b) Du, M.; Zhang, Z.-H.; Wang, X.-G.; Zhao, X.-J. Inorg. Chim. Acta 2009, 362, 1358-1360; (c) Furukawa, H.; Go, Y. B.; Ko, N.; Park, Y. K.; Uribe-Romo, F. J.; Kim, J.; O'Keeffe, M.; Yaghi, O. M. Inorg. Chem. 2011, 50.9147-9152.

30. Seo, J.; Matsuda, R.; Sakamoto, H.; Bonneau, C.; Kitagawa, S. J. Am. Chem. Soc. 2009, 131, 12792-12800.

31. Cabeza, A. J. C.; Day, G. M.; Motherwell, W. D. S.; Jones, W. Chem. Commun. 2007, 1600-1602.

32. Chang, H.; Fu, M.; Zhao, X. J.; Yang, E. C. J. Coord. Chem. 2010, 63, 3551-3564.

33. Zhu, S.; Zhang, H.; Zhao, Y.; Shao, M.; Wang, Z.; Li, M. J. Mol. Struct. 2008, 892, 420-426.

For Table of Contents Use Only

Single-crystal-to-single-crystal transformation of a novel 2-fold interpenetrated cadmium-organic framework with trimesate and 1,2-bis(4-pyridyl)ethane into the thermally desolvated form which exhibits liquid and gas sorption properties

\author{
Ahmad Husain $^{\mathrm{a}}$, Mario Ellwart ${ }^{\mathrm{b}}$, Susan A. Bourne ${ }^{\mathrm{a}}$, Lars Öhrström ${ }^{\mathrm{c}}$ and Clive L. Oliver ${ }^{\mathrm{a} *}$
}

\title{
Synopsis
}

A novel MOF namely $[\mathrm{Cd}(\mathrm{HBTC}) \mathrm{BPE}]_{\mathrm{n}} \cdot \mathrm{nDMF}$ has been synthesized and evaluated for temperature-induced single-crystal-to-single-crystal transformation. It was subjected to various liquids and gases for sorption studies. Structures of the as-synthesized, desolvated and resolvated in benzene have been studied. X-ray analysis revealed a 2-fold interpenetrated, 
3-dimensional framework which exhibits a 3,5-connected network with the Schläfli symbol of $\left[\left(6^{3}\right)\left(6^{9} .8\right)\right.$ and $h m s$ topology.

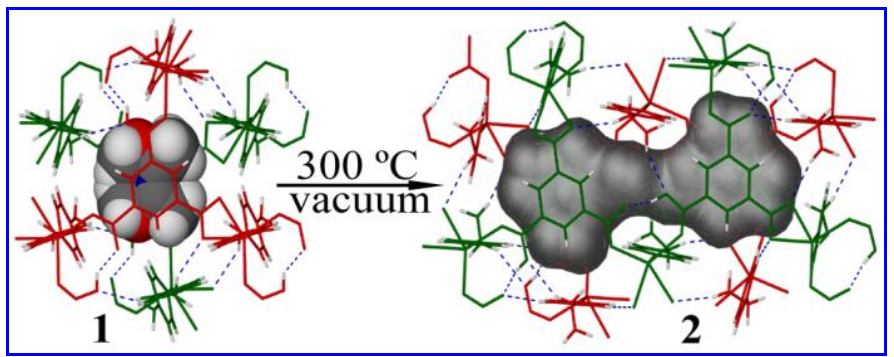

